\title{
Translanguaging in the communicative practice of buyers and sellers in traditional market
}

\author{
Munirah $^{1}$, Aziz Thaba ${ }^{2}$, and Akram Budiman Yusuf ${ }^{3}$ \\ ${ }^{1}$ Indonesian Language and Literature Education Study Program, Pascasarjana, \\ Muhammadiyah University of Makassar, South Sulawesi, Indonesia \\ ${ }^{2}$ Matutu Non-Governmental Educational Research \& Development Institute, South Sulawesi, Indonesia \\ ${ }^{3}$ Indonesian Language and Literature Education Study Program, Faculty of Teacher Training and Education, \\ Muhammadiyah University of Makassar, South Sulawesi, Indonesia
}

\begin{abstract}
The purpose of this study is to examine the translanguaging practice of buyers and sellers in a traditional market in Palopo, South Sulawesi, Indonesia. Translanguaging is a relatively new term in contemporary linguistics. By using the qualitative method, this current study presents an alternative perspective to describe the existence of discrete languages and multilingualism by combining different language features and offers a critical assessment of the theory of bilingualism proposed by Waring (2013) and Garcia and Otheguy (2014) by drawing upon empirical data at our disposal. This study indicates some insightful characteristics of translanguaging practice performed by buyers and sellers. It consists of types, forms, functions, and factors. Firstly, the types of translanguage practices are internal, foreign words, and hybrid aspects. Secondly, this study managed to categorize the practice of translanguage in buyers' and sellers' interactions in three features, namely basic word insertions, invented word insertions, loan word insertions, phrase insertions, reduplications, and regional language particle insertions. This study is not intended to challenge or reject code-switching analyses previously reported by other scholars. However, it challenges the way those scholars' view this real sociolingustic language phenomenon through the theory of translanguaging. In summary, a multilingual community such as a traditional market in Palopo, South Sulawesi, represents the emergence of an awareness of language users to entertain social, cultural, and political entities in the practice of communication. Such awareness is reflected in people's translanguaging structural utterances in their exchanges.
\end{abstract}

Keywords: Communication; community; multilingualism; translanguaging

\begin{tabular}{|c|c|c|}
\hline $\begin{array}{l}\text { First Received: } \\
\text { 20 February } 2021 \\
\text { Final Proof Received } \\
25 \text { September } 2021 \\
\end{array}$ & $\begin{array}{c}\text { Revised: } \\
29 \text { May 2021 }\end{array}$ & $\begin{array}{r}\text { Accepted: } \\
\text { 14 July } 2021 \\
\text { Published: } \\
\text { 30 September 2021 }\end{array}$ \\
\hline $\begin{array}{l}\text { How to cite (in APA style): } \\
\text { Munirah, Thaba, A., \& Yusuf, A. B } \\
\text { buyers and sellers in tradition } \\
\text { 254-268. https://doi.org/10.17 }\end{array}$ & $\begin{array}{l}\text { 1). Translangu } \\
\text { rket. Indonesia } \\
\text { jal.v11i2.3602 }\end{array}$ & $\begin{array}{l}\text { in the communicative practice of } \\
\text { rnal of Applied Linguistics, } 11(2) \text {, }\end{array}$ \\
\hline
\end{tabular}

\section{INTRODUCTION}

The research area of translanguaging conveniently falls into the field of sociolinguistics. This is because this particular area exists within a speech community that has the habit of blending words, phrases, or even sentences from two languages or more. Tranlanguaging is a truly socialinguistic fact which currently is becoming more and more common as people from different ethnic or racial backgrounds move around and interact with one another in genuinely social contexts, specifically in this globalization era.

In recent years, scholars in the area of sociolinguistics broadly have paid attention to and worked with translanguaging. The concept of translanguaging is not really a new term in

\footnotetext{
*Corresponding Author

Email: munirah@unismuh.ac.id
} 
contemporary linguistics because it has been around for more than at least a decade. The conceptual spectrum of translanguaging is derived from the controversy of the existence of discrete languages (Blommaert, 2010; Davidson, 1986; Harris, 1981; Heller, 2007; Heller \& Duchene, 2007; Kemp, 2009; Kravchenko, 2007; Makoni \& Makoni, 2010; Makoni \& Pennycook, 2007; Pennycook, 2006).

Garcia and Otheguy (2019) believe that the practice of translanguaging is related to the disruption of the concept of named languages and the power hierarchies. However, the practice of mixing language cannot be put in only socialcommunal interaction. Wilson (2021) has proved that parental ideologies also have evolved towards more positive attitudes towards language mixing. Moreover, the attitudes towards translanguaging do not necessarily result in the use of flexible language produced at home.

The concept of translanguaging is actually potential to be used to analyze the linguistic practice of mixing languages in a naturally sociolinguistic setting as in a market where buyers and sellers communicate intensively exerting all sorts of different powers relations during such interactions. Such communication is essentially built upon several linguistic components that are arranged in such a way to constitute meaningful exchanges which are potentially ideologically-laden. The languages produced by buyers and sellers in grammatical units of a particular language can manifest in the blending of several forms and words from different languages. Such linguistic units might include basic words, invented words, compound words, loan words, phrases, clauses, and reduplications (Coulmas, 2013; Holmes, 2013; Rahim et al., 2020; Vinansis, 2011).

Traditionally, the phenomenon of sociolinguistic exchanges involving different languages might be examined by employing codeswitching and code-mixing theories. However, with the increasing demand for in-depth description and explanation in linguistic research, these theories are becoming more and more insufficient. This is probably because most of these theories are deeply rooted in structuralism. Apparently, most studies on code-mixing and code-switching have so far gotten bogged down in merely describing linguistic patterns as such without interpreting what these patterns mean socially. In other words, they lack a critical perspective which does not seem to fit well in the qualitative research paradigm. Qualitative linguistic research tends to require more explanation in addition to linguistic description.

The fundamental reason of development of translanguaging is that existing terms such as codemixing and code-switching are argued to be unable to portray the creative and critical issues of certain utterances. In formal discussion, translanguaging has no intention to entertain the dichotomy of indigenous-immigrant, majority-minority, artificialideological. This is because, to a large extent, dichotomizing people into different labels is not fair, especially if such labels are degrading. Such modifiers as indigenous, for example, may bring up negative connotations of being uncultured and close-minded. Similar negative connotations may apply to immigrants. One example could be Muslim immigrants in France are often considered to be poor and uneducated. Such ideological biases can be revealed by undertaking translanguaging research because this kind of research takes into account social and pragmatic contexts.

Essentially, translanguaging focuses more on the practice of transforming the power relations, meaning making process, enhancing experience, and developing identity on multilingual practices (Garcia, 2009; Creese \& Blackedge, 2015). Therefore, it discusses beyond linguistic structural phenomena; it examines both the practice and the process. By taking the translanguaging concept, the practice of integrating different languages and varieties is dynamically and functionally understood as a process of knowledge construction.

Generally, people perform the mixing of languages in an interaction with other people for certain purposes. It can be assumed as a significant role to support the achievement of communication goals of a speaker to an interlocutor. It is acknowledged that there are at least three functions of the practice in a communication setting (Aslinda, 2007; Chaer \& Agustina, 2004, 2010; Haryono, 2012). The functions include (1) as an argumentative means to further convince the speech partner; (2) as a persuasive tool to persuade or to instruct the speech partner; and (3) to emphasize certain intentions. Closely related to these three functions, the practice can be in the forms of linguistic and non-linguistic aspects. Linguistic factors include low frequency of word, pernicious homonymy, oversight, and end factor (purpose and goal). Non-linguistic factors include need for synonyms or the principle of politeness and politeness of speakers, social values or identification of the role or social status of speakers, development and introduction to new cultures, and speakers who need to interpret or to explain what they want (Campbell-Kibler, 2010a; Campbell-Kibler, 2010b; Chambers, 2007; Holmes, 2013; Meyerhoff, 2018; Schiffrin, 1996; Spolsky, 1998; Wardhaugh, 2011). Therefore, people in the respective community should have performed supportive competency in different languages (Rowe, 2018). This is certainly challenging but it is also an exciting opportunity to draw upon the translanguaging abilities of people in traditional market community.

Studies on the practice of translanguaging in a traditional market are fairly limited since most prior studies focus on the translanguaging practices of young emergent bilinguals and multilingual in early 
childhood, kindergarten, and elementary education (Bauer et al., 2017; Gort \& Sembiante, 2015; Martınez-Roldan, 2015; Pontier \& Gort, 2016; Schwartz \& Asli, 2014). Therefore, the present study is significant to fill the relative vacuum of research in this new area of translanguaging in a more authentic and traditional setting.

To a certain extent, it is actually still problematic to accept the practice of mixing of languages by people who are from a monolinguistic background. This is because there may be still a generally negative perception of bilinguals who often switch and mix languages in countries such as the US where these people are mainly from Latin American countries. These people are often fluent in English and Spanish. Even Donald Trump once referred to these people as "Mexican rapists" in one of his Presidential campaigns (BBC, 2016). However, it is a fact that the practice essentially shows dynamic and creative linguistic processes in using one's language mixed with other languages or varieties. In a multilingual area, the practice has also been to be common and, to some extent, has presented a cultural identity. Therefore, the progress of accepting different languages coexisting alongside each other should be started soon. It is a part of the spirit of accepting the existence of different languages in the daily practice of communication.

It turns out that the phenomenon of translanguaging can also be found in Palopo, South Sulawesi, Indonesia. More specifically, in the traditional market, people with diverse ethnic and linguistic backgrounds interact and use their multilingual skills for various purposes such as making offers, convincing buyers, and attracting customers. As an initial observation of this study, it indicated that it is inevitable for the people, who are multilingual speakers, to use the mixing of languages during their intercultural interactions in the market. Various ethnic languages are massively spoken in the whole area, but the people use the Buginese language as a language for their community.

This study is not intended to replace the existing literature on codeswitching. It actually has a different perspective from codeswitching research. Codeswitching studies generally merely focus on the structural aspects of the mixing of languages such as the use of syntactic and morphological features in the mixing process. Like other translanguaging studies, this article aims to uncover the functional aspects or the pragmatic functions of the mixed linguistic features employed in exchanges among speakers beneath the structural features employed by speakers.

Using empirical data from the Palopo market, this article presents a critical assessment of the theory of bilingualism proposed by Waring (2013) and Garcia and Otheguy (2014). This is an alternative angle to understand and analyze the existence of discrete languages and multilingualism by combining different language features. It is a fact that the Indonesian language is used primarily in national interaction settings. Regional languages are used in local or internal interactions of respective ethnic groups. The situation leads to intercultural and language contact-making most Indonesians polyglots (knowing Indonesian and regional languages).

\section{METHOD}

Considering all the above-mentioned background, this study aims to examine the translanguaging practice of buyers and sellers in a traditional market in Palopo, South Sulawesi, Indonesia. In particular, it was designed to describe the forms, functions, and factors involved in such a realistic social communication setting.

The subjects of the study were 2 buyers ( 2 females and 2 males) and 4 sellers ( 2 females and 2 males) found in the Palopo market. All of them were grownups aged from 25 to 40. They were Bugisi, Javanese, Makassarese, and Torajan by ethnicity. Thus, they were valid as research participants. Consents were obtained after the recording had taken place. This was because we intended to obtain data as genuine and as natural as possible.

The empirical analysis drew on a corpus of 13 audio-recorded talks. This took place in a traditional market and was carried out with the following steps. Firstly, observations were conducted several times to observe and record communication interactions between sellers and buyers. Secondly, the data collected were transcribed and categorized according to their patterns and presented as verbatim data.

Table 1

Audio-Recorded Data

\begin{tabular}{rlc}
\hline No & Code & Duration of Recorded Conversation \\
\hline 1. & JCK01 & $00: 10: 15$ \\
2. & BBCK01 & $00: 08: 17$ \\
3. & BBCK02 & $00: 11: 23$ \\
4. & BBCK03 & $00: 07: 41$ \\
5. & BBCK04 & $00: 14: 21$ \\
6. & BBCK05 & $00: 09: 35$ \\
7. & BBCK06 & $00: 11: 46$ \\
8. & FCK01 & $00: 13: 16$ \\
9. & FCK02 & $00: 10: 15$ \\
10. & FCK03 & $00: 10: 28$ \\
11. & FTCK01 & $00: 12: 17$ \\
12. & FTCK02 & $00: 08: 03$ \\
13. & FTCK03 & $00: 12: 39$ \\
\hline
\end{tabular}

For the purpose of this research, the present study in some aspects adopted a case study approach by focusing the analysis on how communities interacted in a certain place (see Waring, 2013). This was an attempt to put aside the personal 
experience of the researchers so that the focus on analyzing this data can be objectively displayed.

The next step was to develop a list of key statements of the respondents. Statements from interview data and other data sources about how the respondents experienced a topic were documented into a list of important statements. This process, called horizontalizing the data, aimed to avoid repeating or making overlapping statements.

The next process was called developing 'meaningful units'. In this process, important statements generated from the horizontalizing process were combined into meaningful units. Based on these units, verbatim examples and text explanations can be identified. These experiences were then analyzed in the 'structural description' stage, where the background and state of the phenomenon experienced by the subject were described and reflected through an interview.

Finally, the 'composite description' combined two descriptions from the previous stage were written, consisting of the textual description and the structural description. This final stage included the essence of respondents' experiences and described the pinnacle aspect of phenomenological research. This stage took the form of a long paragraph that tells the reader "what" experiences with the phenomenon that the respondents had and "how" they experienced the phenomenon.

\section{FINDINGS}

The findings begin with the general type of translanguaging practices identified in buying and selling interactions. It is related to the internal differentiation of specific codes.

\section{Excerpt 1: JCK01}

\begin{tabular}{|c|c|c|c|c|c|}
\hline \multirow[t]{2}{*}{ Buyer } & : & $\begin{array}{l}\text { Tabe, } \\
?\end{array}$ & $\begin{array}{l}\text { bisa } \\
\text { can }\end{array}$ & $\begin{array}{l}\text { lihat } \\
\text { see }\end{array}$ & $\begin{array}{l}\text { yang } \\
\text { which }\end{array}$ \\
\hline & & \multicolumn{4}{|c|}{ Can I see that one (pointing to the hanging clothes) } \\
\hline \multirow[t]{3}{*}{ Seller } & : & $\begin{array}{l}\text { Tabe, } \\
?\end{array}$ & $\begin{array}{l}\text { coba } \\
\text { try }\end{array}$ & $\begin{array}{l}\text { maki } \\
?\end{array}$ & $\begin{array}{l}\text { dulu, } \\
\text { before }\end{array}$ \\
\hline & & \multicolumn{4}{|c|}{ Excuse me (while giving the clothes to the buyer), } \\
\hline & & $\begin{array}{l}\text { kalau } \\
\text { if }\end{array}$ & $\begin{array}{l}\text { cocok bisa } \\
\text { suitable }\end{array}$ & $\begin{array}{l}j i \\
\text { can }\end{array}$ & $\begin{array}{l}\text { nego. } \\
?\end{array}$ \\
\hline
\end{tabular}

It can be seen that the dialogue displayed internal language features. Both participants used inner codes of language such as in Tabe, bisa lihat yang itu (Excuse me, can I see that one) and Tabe (Here it is), coba maki dulu, kalau cocok bisa ji nego (just try it first. If it fits, we can negotiate). The words tabe and maki are Buginese words that are inserted in an Indonesian sentence.

Furthermore, the practices of using foreign languages can also be identified. It happened in the dialogue when the seller said: Thank you kak, datang ki lagi lain waktu nah (Thank you, sis. Please come again next time). The phrase thank you is an English expression that is inserted in the Indonesian sentence. The hybrid practice can also be identified when the seller says Di belakang rak itu $k i$ ' ada fitting room (There is a fitting room behind the shelf). The phrase fitting room is an English term, which is used together with the Buginese particle $k i^{\prime}$.

\section{Excerpt 2: BBCK01}

$\begin{array}{ll}\text { Buyer : } & \text { Tidak cepat kropos ji besinya le ji? } \\ & \text { Does the iron not porous quickly? } \\ \text { Seller : } & \begin{array}{l}\text { De to, aluminium je ye,,, kuat } \\ \text { Tidak dong, alumunium ini ya,,, kuat } \\ \text { Yes, it is aluminium. It is strong }\end{array}\end{array}$

itu

that

negotiate
For a more detailed classification, the present research categorized the practice of translanguaging in buyers and sellers interactions in three features, namely basic word insertion, invented word insertion, loan word insertion, phrase insertion, reduplication, and regional language particle insertion. The description of the findings is shown as follows.

\section{Basic word insertion}

The analysis revealed that there are 217 forms of insertion of basic words in the data. It consisted of words from Indonesian, Bugisi, Javanese, Makassar, and Torajan. Excerpt 2 is a sample dialogue between a bicycle seller, who is Bugisi, and a Javanese buyer. The words aluminium and kuat (strong) are basic words in Indonesian lexicons that are inserted in a Buginese sentence. 
The data show that the speakers seem automatic without thinking to put the Indonesian lexicon on their utterances. It can be assumed that they perform such utterances in daily communication or Indonesian lexicons have more sense to construct the intended meaning.

\section{Excerpt 3: BBCK02}

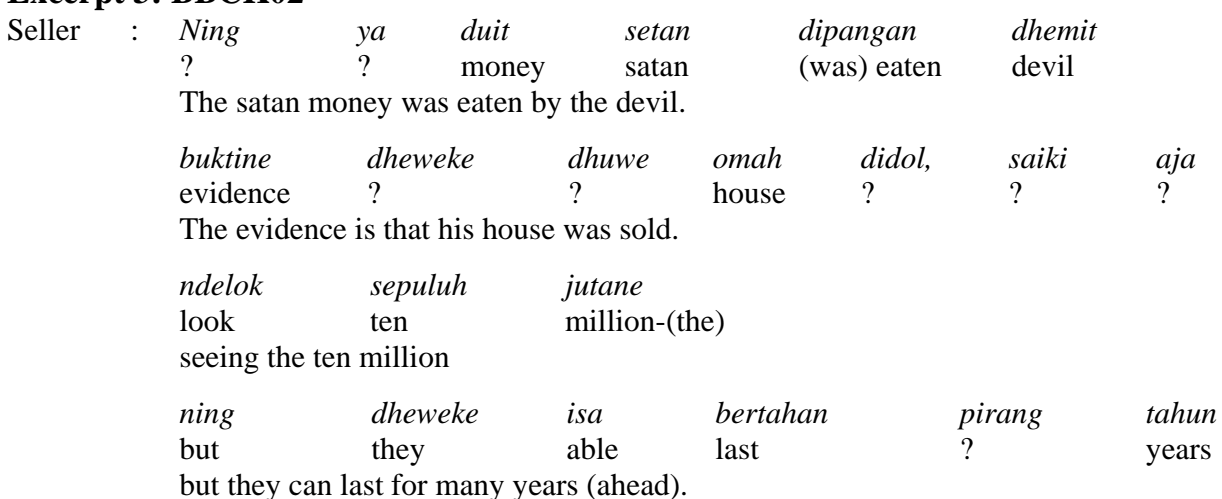

The example of the occurrence of invented word is when the seller says, "Ning ya duit setan dipangan dhemit, buktine dheweke dhuwe omah didol, saiki aja ndelok sepuluh jutane, ning dheweke isa bertahan pirang tahun" (The money was eaten by the devil. The evidence is that own house was sold. Look at ten million, but they can last for many years). The word bertahan (lasting) is an Indonesian word that is formed by the prefix "ber-"

\section{Excerpt 4: BBCK03}

\begin{tabular}{|c|c|c|c|c|c|c|}
\hline \multirow[t]{4}{*}{ Seller } & $\begin{array}{l}\text { Pokoknya } \\
\text { The main }\end{array}$ & $\begin{array}{l}\text { seтиа } \\
\text { all }\end{array}$ & $\begin{array}{l}\text { bagian } \\
\text { part }\end{array}$ & \multicolumn{3}{|c|}{$\begin{array}{l}\text { depannya } \\
\text { front }\end{array}$} \\
\hline & $\begin{array}{l}\text { kayaknya } \\
\text { seem }\end{array}$ & $\begin{array}{l}\text { harus } \\
\text { must }\end{array}$ & $\begin{array}{l}\text { diganti. } \\
\text { (be)replaced }\end{array}$ & & & \\
\hline & \multicolumn{6}{|c|}{ All the front seems to be replaced. } \\
\hline & $\begin{array}{l}\text { Speedometernya } \\
\text { The speedometer }\end{array}$ & $\begin{array}{l}\text { bisa } \\
\text { able }\end{array}$ & $\begin{array}{l}\text { sampai } \\
\text { until }\end{array}$ & $\begin{array}{l}\text { peccah } \\
\text { break }\end{array}$ & $\begin{array}{l}\text { begini } \\
\text { like this }\end{array}$ & $\begin{array}{l}\text { Pembalap } \\
\text { what a racer }\end{array}$ \\
\hline
\end{tabular}

The loan word can be identified when the mechanic says: Pokoknya semua bagian depannya kayaknya harus diganti. Speedometernya bisa sampai pecah begini. Pembalap (The point is [that] all the front part seems to need replacement. The speedometer is broken like this.... What a racer). The word speedometer is a foreign word that has been codified into the Indonesian language. It was inserted when the speaker spoke in Indonesian.

\section{Invented word insertion}

Based on the analysis, there are 81 forms of insertion of invented words in Indonesian, Bugisi, Torajan, Javanese, and Makassar languages. Excerpt 3 displays a dialogue between a vegetable seller and a buyer who are both Javanese. It shows the practices of insertion of invented words.

and the basic word "tahan". The word is inserted into a Javanese sentence.

\section{Loan word insertion}

The analysis of loan word insertion shows that there are 18 forms with loan word insertions and 31 insertions of cognate words. The following excerpt is a dialogue between a repair shop mechanic and a customer repairing a motorbike damaged by an accident. Both are Bugisi.

\section{Excerpt 5: BBCK04}

$\begin{array}{lllllll}\text { Seller }: \begin{array}{llll}\text { Double } \\ \text { double }\end{array} & \text { starter } & k i & \text { saja } & \text { seperti } & \text { ini. } \\ & \text { starter } & ? & \text { just } & & \text { like } \\ & \begin{array}{l}\text { Bagus } \\ \text { good }\end{array} & m i & \text { itu } & & & \\ & & \text { that } & & \end{array}$

Just double starter [the motorcycle] like this. It will be good again 
The phrase insertion was found when the mechanic said: Double starter ki saja seperti ini. Bagus mi itu ([You] just double starter it like this. It will be good again). The words double and starter are foreign words that form a phrase.

\section{Excerpt 6: BBCK05}

Seller : Pasar

market

mandet-mandet

?

The market here is not that good. The management is stagnant.

\section{Reduplication}

The analysis reveals that there are 71 forms of reduplication. The following excerpt is a dialogue between a Torajan seller and a Javanese buyer.

$\begin{array}{lll}\text { kurang } & \text { bagus } & \text { mas, } \\ \text { less } & \text { good }\end{array}$

The insertion of reduplication can be identified when the seller says: Pasar disini kurang bagus mas, mandet-mandet pengelolaannya (The market here is not really good. The management is stagnant). The word mandet (stagnation) is a Javanese word that is inserted into an Indonesian sentence in the form of reduplication becoming mandet-mandet (stagnant). In addition, this study also identified the insertion of particles of regional languages. The findings are presented below.

\section{Regional language particle insertion}

Based on the analysis, there are 217 code mixings with the insertion of regional language particles. The following excerpt displays a dialogue between a Bugisi seller and a Torajan buyer.

\section{Excerpt 6: BBCK06}

\begin{tabular}{|c|c|c|c|c|c|c|c|}
\hline Seller & : & $\begin{array}{l}\text { Masuk } \\
\text { Come-in }\end{array}$ & $\begin{array}{l}k i^{\prime \prime} \\
?\end{array}$ & $\begin{array}{l}\text { liat-liat } \\
\text { look }\end{array}$ & $\begin{array}{l}\text { barang-nya } \\
\text { item-(the) }\end{array}$ & & \\
\hline & & Please cor & ee in and & a look at our ite & & & \\
\hline uyer & & $\begin{array}{l}\text { Coba } \\
\text { try }\end{array}$ & $\begin{array}{l}\text { warna } \\
\text { color }\end{array}$ & $\begin{array}{l}\text { toskahnya, } \\
\text { tosca }\end{array}$ & $\begin{array}{l}\text { ukurannya } \\
\text { size-(the) }\end{array}$ & $\begin{array}{l}\text { kayak } \\
\text { like }\end{array}$ & $\begin{array}{l}\text { ini } \\
\text { this }\end{array}$ \\
\hline
\end{tabular}
I need the tosca one with the same size like this one.

It can be seen that there are some parts containing insertion of particles of Bugisi and Torajan languages, such as " $k i$ "“ (Bugisi), "ji" (Bugisi), "ta" (Bugisi or Torajan), " $m i "$ (Bugisi), "mo" (Makassar), "le" (Torajan), "bah" (Buginese or Makassar), "be" (Torajan), "ha" (Buginese), "sa" (Buginese) and "toh" (Bugisi).

Moreover, the analysis of functions of translanguaging in buyers and sellers interaction shows that there are three functions of code-mixing in the interactions between sellers and buyers. They are (1) as an argumentative means to convince a speech partner; (2) to strengthen the function of persuasive and directive to speech partner; and (3) to emphasize certain intentions.

\section{Argumentative means to convince a speech partner}

As revealed by the analysis, there were 28 code mixings that were intended to convince the speech partners. The following excerpt displays a dialogue between a Bugisi seller and a Torajan buyer.

\section{Excerpt 7: FCK01}

\begin{tabular}{|c|c|c|c|c|c|c|c|}
\hline \multirow[t]{3}{*}{ Buyer } & $\begin{array}{l}b e \ldots \\
?\end{array}$ & why & $\begin{array}{l}\text { kenapa } \\
\quad \text { expensive } \\
\text { why }\end{array}$ & $\begin{array}{l}\text { mahal } \\
\text { once } \\
\text { expensive }\end{array}$ & $\begin{array}{c}\text { sekali } \\
\text { ma'am SBJ } \\
\text { very }\end{array}$ & $\begin{array}{l}\mathrm{Bu} \\
\text { ma'am }\end{array}$ & $\begin{array}{l}\text { Aji, } \\
?\end{array}$ \\
\hline & $\begin{array}{l}\text { tokoh } \\
\text { SBJ } \\
\text { booth }\end{array}$ & LOC & at $\mathrm{LOC}$ & $\begin{array}{l}\text { sana } \\
\text { there }\end{array}$ & $\begin{array}{l}\text { tadi } \\
\text { before }\end{array}$ & $\begin{array}{l}\text { agak } \\
\text { less }\end{array}$ & $\begin{array}{l}\text { murah } \\
\text { cheap }\end{array}$ \\
\hline & $\begin{array}{l}\text { pasempoi } \\
\text { ? }\end{array}$ & & $\begin{array}{l}\mathrm{Bu} \\
\text { ma'am }\end{array}$ & $\begin{array}{l}\mathrm{Aji} \\
?\end{array}$ & $\begin{array}{l}\text { sedikit } \\
\text { slightly }\end{array}$ & $\begin{array}{l}\text { oh.. } \\
?\end{array}$ & \\
\hline
\end{tabular}

Why is it so expensive, Ma'am? The booth there, is cheaper. Lower it more a bit, Ma'am.

The buyer performed a translanguaging practice by saying "be...kenapa mahal sekali Bu Aji, tokoh di sana tadi agak murah ji, pasempoi Bu Aji sedikit" (oh... why is it so expensive Bu Aji? The shop there puts a cheaper price. please make it less a bit $\mathrm{Bu} \mathrm{Aji).} \mathrm{The} \mathrm{practice} \mathrm{is} \mathrm{in} \mathrm{the} \mathrm{form} \mathrm{of} \mathrm{phrase}$ insertion of an Indonesian expression "mahal sekali" (very expensive) into the Bugisi sentence; and, vice versa, a Bugisi word "pasempoi" (reduce) was inserted into an Indonesian sentence. The function is 
to put forward a convincing argument to the seller to sell with a lower price, like other sellers.

\section{Strengthening the functions of persuasive and directive to speech partner}

The result of the analysis shows that there were 28 forms that are intended to strengthen persuasion and directives to the speech partner. Excerpt 8 displays a dialogue between a seller and a buyer, who are both Bugisi.

The buyer performed a translanguaging practice by saying akkutanai banni the banknge, the mappada yaro pelayaanna? (Just ask the bank, why is the service like that?). It is in the form of phrase insertion of an Indonesian expression "pihak bank" (the bank) into the Bugisi sentence. The insertion has two functions. Firstly, it is to be more persuasive to influence and to convince the actions or attitudes of the speech partner. Secondly, it is to persuade or instruct the speech partner to ask or to report to the bank.

\section{Emphasizing certain intentions}

Based on the analysis, there are 42 code-mixing events that function to emphasize certain intentions. Excerpt 9 presents a dialogue between a Bugisi seller and a Javanese buyer.

\section{Excerpt 8: FCK02}

(Two buyers were discussing with the shop owner's wife the banking problems they were facing. The discussion was held in a cosmetic shop)

$\begin{array}{lllll}\text { Seller } \quad: \quad \text { akkutanai } & \text { banni } & \text { pihak } & \text { banknge, } \\ & ? & ? & ? & ? \\ & \text { masa } & \text { mappada } & \text { yaro } & \text { pelayaanna? } \\ & ? & ? & ? & ?\end{array}$

Just ask the bank, why is the service like that?

\section{Excerpt 9: FCK03}

Seller : Awe, gampang sekali ji. Matu engka untung riputawa pole pesanatta umpama kita membeli lima ribu, sepuluh ribu mi kita jualkan. Jadi dapat maki untung lima ribu. Tapi idi" sa mauki jual berapa. Contoh ji tadi itu saya kasiki

Well, it is so easy. Later they will be obtained from the order. For instance, you buy it for five thousand rupiahs, then you sell it for ten thousand rupiahs. Therefore, you can make a profit of five thousand rupiahs. However, it is up to you to determine the price. That is just an example.

The buyer performed a translanguaging practice by saying Awe, gampang sekali ji. Matu engka untung riputawa pole pesanatta umpama kita membeli lima ribu, sepuluh ribu mi kita jualkan. Jadi dapat maki untung lima ribu. Tapi idi'sa mauki jual berapa. Contoh ji tadi itu saya kasiki (Translation: Well, it is so easy. Later, it can be obtained from the order. For example, you buy it for five thousand rupiahs, then you sell it for ten thousand rupiahs. Therefore, you can generate profit for five thousand rupiahs. However, the selling price is up to you. I just propose an example). It is in the form of a phrase insertion of an Indonesian expression mauki jual berapa (how much [do you] sell) into the Indonesian sentence. The insertion has the intention to reaffirm the previous explanation to make the speech partner better understanding.
Therefore, the function is to emphasize certain meanings.

By doing further analysis, the factors that cause the use of translanguaging features are related to some distinctive aspects. The aspects are related to the identification of the role or social status of the speaker, the principle of politeness and politeness of the speaker, and the intention of the performer to interpret or to explain something.

The identification of the role or social status of the speaker

As shown by the analysis, there were 113 translanguaging forms that refer to role or social status factors. The following excerpt is a dialogue between a seller and a buyer, who are Bugisi.

\section{Excerpt 10: FTCK01}

Seller : $\quad$ Iye bu insyaAllah, semoga kodong nanti ada juga anak ku yang bisa kayak anak ta. Tabe bu, duduk maki dulu saya carikan ki yang kita cari.

Yes ma'am, Insya Allah, hopefully, my children can be like yours. Excuse me ma'am, just sit down first I will look for the goods that you are looking for.

The seller performed a translanguaging practice by saying "Iye bu insyaAllah, semoga kodong nanti ada juga anak ku yang bisa kayak anak ta. Tabe bu, duduk maki dulu saya carikan ki yang kita cari. (Yes ma'am, By God willing, I hope my child can be like yours. Excuse me, Ma'am, please sit down, I'll look for the goods that you are looking for). The word kodong is a Buginese word that is inserted into Indonesian sentences. Kodong in the speech shows the expectation of the speaker, 
which is not in a better condition than the partner. The speaker hopes that in the future his condition will be as good as the speech partner. In other words, the word kodong was used by the speaker to identify a higher social status or role.

\author{
The principle of politeness and politeness of the \\ speaker \\ In Excerpt 11, both the seller and the buyer are \\ Bugisi. The translanguaging happened in the form \\ of insertion of basic words and regional language \\ particles, such as tabe, iye, $k i^{\prime}$, and di'.
}

\author{
Excerpt 11: FTCK02 \\ Buyer : Ada yang lengannya tiga perempat? \\ Is there any of them who has $3 / 4$ sleeves? \\ Seller : Tunggu saya cek dulu kak. Semoga masih ada. Mauki warna apa biar sekalian mi? \\ Wait a minute, I'll check it first. I hope there is. What color do you want as well? \\ Buyer : Iye, coba warna hitam sama warna abu-abu. \\ Yes, black and grey please. \\ Seller : Tunggu $d i$ \\ Please wait
}

The basic words and the particles of the Bugisi are inserted into an Indonesian sentence. The words tabe and iye, and the particles $k i$ ' and $d i$ ' are used naturally to give the highest appreciation to the speech partner. In the context of the dialogue, the words and the particles are mixed into Indonesian sentences as an effort of the speaker to adhere to the principles of politeness.

\title{
Excerpt 12: FTCK02 \\ Seller : Siaga pale idi melo? \\ So, how much do you want? \\ Buyer : (silent without answering) \\ Seller : Siaga? Berapa kita mau pale na ndi? \\ How much? How much do you want then, sis? \\ Buyer : Kasi pas mi harganya 100 om \\ Can I have it for one hundred thousand rupiahs, uncle?
}

\section{The intention of the performer to interpret or to explain something}

As shown by the analysis, there are forms that refer to the intention to interpret or to explain something. The following excerpt is a dialogue between a seller and a buyer, who are Bugisi and Javanese.
In the dialogue, the seller repeated the questions addressed to the Buyer. First, the seller said, Siaga pale idi melo? (So, how much do you want?). However, the buyer did not respond to the question. Therefore, the seller asked again, Siaga? Berapa kita mau pale na ndi? (How much? How much do you want then, sis?). The seller performed inner code-mixing by inserting Indonesian phrases into a Bugisi sentence. In other words, the seller mixed the code on the second question because the seller had understood that the buyer did not understand the question due to language differences. The buyer who is a Javanese did not understand the question in a full Bugisi sentence. Therefore, to make it easier for the buyer, the seller mixed the code by inserting the Indonesian phrases.

\section{DISCUSSION}

The analysis of the present research attempts to describe each form of translanguaging performed by buyers and sellers. The speakers can be said to use a single language structure which they drew linguistic features strategically. The structure is referred to the
Indonesian standard language. However, the mental grammars of the speakers retain some level of internal differentiation reflective of distinct codes (MacSwan, 2017, p. 172). It must be noted that the term "translanguaging" was not originally intended as a theoretical concept, but a descriptive label for specific language practice.

The analysis results have shown that the language choice would be reversed when the sellers or buyers would understand or be aware of specific information from their interlocutors. Such practices were by no means unique to the context of interaction. However, instead of viewing them as a non-standard language in the interaction of bilingual speakers, the analysis shows that it is more suitable for speakers to maximize their own linguistic resources from regional, national, or global languages. It confirms the prior studies that show a fact that translanguaging has proven to be an effective way to communicate in specific situations namely buyers-sellers interaction in different languages, since translanguaging empowers both the speaker and the interlocutor, and shares the power 
relations between two parties, sellers and buyers, (Garcia, 2009; Creese \& Blackledge, 2015).

The practices of translanguaging emphasize the interconnectedness between traditional and conventional norms of languages. The point is about the understood languages in human communication systems. The analysis results show that buyers and sellers' knowledge of language cannot be separated from the concepts of human social interaction. Therefore, the present study shows that it is never too old to follow Pinker (1994) that used 'language instinct metaphor' to describe human beings' innate capacity for acquiring languages. It can be said that buyers and sellers interact in everyday life in more naturalistic and pragmatic processes. It is not merely about the boundaries of grammatical accuracy, it is about achieving effective communication.

In a traditional market setting, multiple cues are present simultaneously in producing an effective interaction of languages. Both sellers and buyers employ a natural drive to draw on as many different resources. It is reasonable as they are in an attempt to transfer, interpret, and achieve the meaning intentions. The variation of translanguaging tools performed by buyers and sellers has sought to underpin the concept.

The idea of the translanguaging instinct of buyers and sellers has implications for sociolinguistic studies. The combination of all available cognitive, semiotic, sensory, and modal resources in daily communication relies on different resources differentially across cultures. The resources are crucial to forming sustainable and effective communication in a different culture of the language.

Since buyers and sellers will be involved in complex communicative settings, the natural tendency to combine multiple resources drives them to look for more cues and exploit different resources. Therefore, Cook (1992) and Cook and Li (2016) believe that it is not always about a formal study on literacy to combining different linguistic resources (e.g. accent, writing) and between linguistic and other cognitive and semiotic resources. It is more about practical issues in combining multiple resources in varied cultures. In the practice of communication, ethnicity can be defined as geographical imagination. However, the speakers can use it in wider contexts to broaden their perspectives on how to produce certain language structures to convey pragmatic meanings.

\section{CONCLUSION}

The study has revealed some characteristics of translanguaging practice performed by buyers and sellers. It consists of types, forms, functions, and factors. Firstly, the types of translanguage practices are internal, foreign words, and hybrid aspects. Secondly, the present research has categorized the practice of translanguage in buyers and sellers interactions in three features, namely basic word insertion, invented word insertion, loan word insertion, phrase insertion, reduplication, and regional language particle insertion.

The regional language particle insertion consists of " $k i$ " (Bugisi), "ji" (Bugisi), "ta" (Bugisi or Torajan), "mi" (Bugisi), and "mo" (Makassar). In addition, study found the particles "le" (Torajan), "bah" (Bugisi or Makassar), "be" (Toraja), "ha" (Bugisi), "sa" (Bugisi) and "toh" (Buginese). Thirdly, there are three functions of translanguaging practices for buyers and sellers, namely (1) as an argumentative means to further convince the speech partner; (2) to strengthen the function of persuasive and directive to the speech partner; and (3) to emphasize certain intentions. Fourthly, the factors that cause the code-mixing are (1) the identification of the role or social status of the speaker; (2) the principle of politeness and politeness of the speaker; and (3) the intention of the performer to interpret or to explain something.

It has been common to say that the labeling of languages is largely arbitrary and can be politically and ideologically charged. Moreover, there is often a relation between identity, ethnicity, and national identity. However, in daily social interaction, buyers and sellers as language users move dynamically between the so-called languages, varieties, styles, registers, and grammar, to reach communicative functions. The present research indicates that translanguaging is a very common feature of human social interaction.

The present research is not intended to challenge or reject code-switching or any other similar terms. The present research promotes the flexible view to deal with real language phenomena in a communication setting where people who speak more than one language are involved. Therefore, future studies should be directed towards researching more linguistic patterns in terms of their pragmatic use of language in realistic social interactions which include an understanding of historical, political, ideological, aspects and social harmony. In summary, a multilingual community such as a traditional market in Palopo, South Sulawesi, represents an awareness of language users to entertain social, cultural, and political entities in the practice of communication. This awareness is displayed in their translanguaging practice of structural utterances.

\section{REFERENCES}

Aslinda, L. S. (2007). Pengantar sosiolinguistik [Introduction to sociolinguistics]. PT Refika Aditama.

Bauer, E. B., Presiado, V., \& Colomer, S. (2017). Writing through partnership: Fostering translanguaging in children who are emergent 
bilinguals. Journal of Literacy Research, 49(1), 10-37. https://doi.org/10.1177/1086296X16683417

BBC. (2016, August 31). Drug dealers, criminals, rapists': What Trump thinks of Mexicans. https://www.bbc.com/news/av/world-uscanada-37230916

Blommaert, J. (2010). The sociolinguistics of globalization. Cambridge University Press.

Campbell-Kibler, K. (2010a). Sociolinguistics and perception. Language and Linguistics Compass, 4(6), 377-389.

https://doi.org/10.1111/j.1749818X.2010.00201.X

Campbell-Kibler, K. (2010b). The sociolinguistic variant as a carrier of social meaning. Language Variation and Change, 22(3), 423441. https://doi.org/10.1017/S0954394510000177

Chaer, A., \& Agustina, L. (2004). Sosiolinguistik: Perkenalan awal. Penerbit PT Rineka Cipta.

Chaer, A., \& Agustina, L. (2010). Sosiolinguistik: Edisi revisi. Penerbit PT Rineka Cipta.

Chambers, J. K. (2007). The blackwell encyclopedia of sociology. John Wiley \& Sons, Ltd.

Cook, V. J. (1992). Evidence for multicompetence. Language Learning, 42(4), 557-591. https://doi.org/10.1111/j.14671770.1992.tb01044.x

Cook, V. \& Li, W. (2016). The Cambridge handbook of linguistic multi-competence. Cambridge University Press.

Coulmas, F. (2013). Sociolinguistics: The study of speakers' choices. Cambridge University Press.

Creese, A., \& Blackledge, A. (2015). Translanguaging and identity in educational settings. Annual Review of Applied Linguistics, $35,20-35$. https://doi.org/10.1017/S0267190514000233

Davidson, D. (1986). A nice derangement of epitaphs. In E. Lepore (Ed.), Truth and interpretation: Perspectives on the philosophy of Donald Davidson (pp. 433-446). Blackwell.

Garcia, O. (2009). Bilingual education in the $21^{\text {st }}$ century: A global perspective. WileyBlackwell.

Garcia, O., \& Otheguy, R. (2019). Plurilingualism and translanguaging:

Commonalities and divergences. International Journal of Bilingual Education and Bilingualism, 23(1), 17-35. https://doi.org/10.1080/13670050.2019.159893 2

Gort, M., \& Sembiante, S. F. (2015). Navigating hybridized language learning spaces through translanguaging pedagogy: Dual language preschool teachers' languaging practices in support of emergent bilingual children's performance of academic discourse. International Multilingual Research Journal, 9(1), 7-25. https://doi.org/0.1080/19313152.2014.981775

Harris, R. (1981). The language myth. Duckworth.

Haryono, A. (2012). Perubahan dan perkembangan bahasa: Tinjauan historis dan sosiolinguistik. Udayana University.

Heller, M. (2007). Bilingualism: A social approach. Palgrave Macmillan.

Heller, M., \& Duchene, A. (2007). Discourses of endangerment: Sociolinguistics, globalization and social order. In A. Duchene \& M. Heller (Eds.), Discourses of endangerment: Ideology and interest in defense of languages (pp. 1-13). Continuum.

Holmes, J. (2013). An introduction to sociolinguistics. Routledge.

Kemp, C. (2009). Defining multilingualism. In L. Aronin \& B. Hufeisen (Eds.), The exploration of multilingualism (pp. 11-26). John Benjamins.

Kravchenko, A. V. (2007). Essential properties of language, or, why language is not a code. Language Sciences, 29(5), 650-671. https://doi.org/10.1016/j.langsci.2007.01.004

MacSwan, J. (2017). A multilingual perspective on translanguaging. American Educational Research Journal, 54(1), 167-201. https://doi.org/10.3102/0002831216683935

Makoni, S., \& Makoni, B. (2010). Multilingual discourse on wheels and public English in Africa: A case for "vague linguistics." In J. Maybin \& J. Swann (Eds.), The Routledge companion to English language studies (pp. 258-270). Routledge.

Makoni, S., \& Pennycook, A. D. (2007). Disinventing and reconstituting languages. In S. Makoni \& A. Pennycook (Eds.), Disinventing and reconstituting languages (pp. 1-41). Multilingual Matters.

Martınez-Roldan, C. M. (2015). Translanguaging practices as mobilization of linguistic resources in a Spanish/English bilingual afterschool program: An analysis of contradictions. International Multilingual Research Journal, 9(1), 43-58. https://doi.org/10.1080/19313152.2014.982442

Meyerhoff, M. (2018). Introducing sociolinguistics. Routledge.

Pennycook, A. (2006). Postmodernism in language policy. In T. Ricento (Ed.), An introduction to language policy: Theory and method (pp. 60-67). Blackwell.

Pinker, S. (1994). The language instinct. William Morrow \& Co.

Pontier, R., \& Gort, M. (2016). Coordinated translanguaging pedagogy as distributed cognition: A case study of two dual language bilingual education preschool coteachers' 
languaging practices during shared book readings. International Multilingual Research Journal, 10(2), 89-106. https://doi.org/10.1080/19313152.2016.115073 2

Rahim, A. R., Arifuddin, A., \& Thaba, A. (2020). Alih kode dan campur kode seller dan buyer di pasar pabbaeng baeng kota Makassar. Kredo: Jurnal Ilmiah Bahasa Dan Sastra, 4(1), 245261. https://doi.org/10.24176/kredo.v4i1.5422

Rowe, L. W. (2018). Say it in your language: Supporting translanguaging in multilingual classes. The Reading Teacher, 72(1), 31-38. https://doi.org10.1002/trtr.1673

Schiffrin, D. (1996). Interactional sociolinguistics. Sociolinguistics and Language Teaching, 4, 307-328.

Spolsky, B. (1998). Sociolinguistics. Oxford University Press.

Schwartz, M., \& Asli, A. (2014). Bilingual teachers' language strategies: The case of an
Arabic-Hebrew Kindergarten in Israel.

Teaching and Teacher Education, 38, 22-32. https://doi.org/10.1016/j.tate.2013.10.013

Vinansis, M. R. (2011). Alih kode dan campur kode bahasa jawa dalam rapat ibu-ibu PKK di Kepatihan Kulon Surakarta (Suatu kajian sosiolinguistik) [Unpublished master thesis]. Universitas Sebelas Maret.

Wardhaugh, R. (2011). An introduction to sociolinguistics. John Wiley \& Sons.

Waring, H. Z. (2013). Managing stancy: A case study of turn-taking in the language classroom. System, 41(3), 841-851. https://doi.org/10.1016/j.system.2013.08.007

Wilson, S. (2021). To mix or not to mix: parental attitudes towards translanguaging and language management choices. International Journal of Bilingualism, 25(1), 58-76.

https://doi.org/10.1177/1367006920909902 